\title{
PENGETAHUAN DAN KEPATUHAN PENDERITA DIABETES MELLITUS DALAM MELAKUKAN LATIHAN FISIK
}

\author{
SUSANTI \\ AKADEMI KEPERAWATAN ADI HUSADA SURABAYA \\ susanti1303@gmail.com
}

\begin{abstract}
Patients with Diabetes Mellitus is necessary therapeutic regimen for prevention or treatment, care to help patients to prevent complications. One is by providing information to physical activity to increase knowledge about the effects of Diabetes Mellitus patients and physical exercise. The purpose of this study was to determine the relationship of knowledge with diabetic patient compliance in physical exercise. The research method is a correlation with cross sectional approach, the research sample are 39 people with purposive sampling technique. The tools used assess knowledge and compliance of respondents using a questionnaire. Data collection is done coding, scoring, and tabulation and correlation test by Spearman Rank Test. The results showed that the results of the statistical test of Spearman rank correlation significance value $(<0.05)$, it shows there is a relationship then $\mathrm{Hl}$ accepted which means that there is a relationship between knowledge and compliance of patients with Diabetes Mellitus in physical exercise. Results of this study can assist clients in improving the quality of life program Diabetes Mellitus patients through regular physical exercise. Suggested to the nurse to use the results of this study as a reference for improving services in diabetic patients leading to the needs of the patient in physical exercise.
\end{abstract}

\begin{abstract}
ABSTRAK
Penderita Diabetes Mellitus membutuhkan tindakan terapeutik untuk pencegahan atau penatalaksanaan, dan tindakan lain untuk mencegah komplikasi. Hal tersebut dapat dilakukan denga menambah informasi tentang aktifitas fisik untuk meningkatkan pengetahuan pasien Diabetes Mellitus. Tujuan penelitian ini untuk mengidentifikasi hubungan antara pengetahuan dengan kepatuhan penderita Diabetes Mellitus dalam melakukan latihan fisik. Metode penelitian menggunakan korelasi dengan pendekatan potong lintang. Sampel terdiri dari 39 responden dan menggunakan teknik purposive sampling. Pengukuran pengetahuan dan kepatuhan penderita Diabetes mellitus dalam melakukan latihan fisik menggunakan kuesioner. Data diolah menggunakan Spearman rank test. Hasil menunjukkan signifikan $(<0,05)$. Hal ini menunjukkan terdapat hubungan antara pengetahuan dan kepatuhan penderita Diabetes Mellitus dalam melakukan latihan fisik. Hasil ini dapat menunjang penderita Diabetes Mellitus untuk meningkatkan kualitas hidup dan dapat digunakan sebagai sumber pustaka bagi perawat dalam meningkatkan pelayanan bagi penderita Diabetes Mellitus dalam melakukan latihan fisik.
\end{abstract}

Keywords: Diabetes Mellitus, Knowledge, Compliance

\section{PENDAHULUAN}

Diabetes mellitus (DM) merupakan penyakit metabolik dengan karakteristik peningkatan kadar glukosa darah (hiperglikemia) yang terjadi akibat kelainan sekresi insulin, kerja insulin atau keduanya. Glukosa dibentuk di hati dari makanan yang dikonsumsi dan secara normal bersirkulasi dalam jumlah tertentu dalam darah. Insulin merupakan suatu hormon yang diproduksi pankreas yang berfungsi mengendalikan kadar glukosa dalam darah dengan mengatur produksi dan penyimpanannya. ${ }^{6}$

Data WHO tahun 2011 jumlah penderita diabetes mellitus di dunia 200 juta jiwa, Indonesia menempati urutan ke empat terbesar dalam jumlah penderita diabetes melitus di dunia. Pada tahun 2011, terdapat sekitar 5,6 juta penduduk Indonesia yang mengidap diabetes. Analisa dari Mc Carty dan Zimmet, terdapat penderita Diabetes Mellitus sekitar 2,5 juta dan pada tahun 2000 meningkat menjadi 4 juta dan diperkirakan pada tahun 2010 mencapai 5 juta penderita. Di Jawa Timur dengan jumlah penduduk 23 juta terdapat minimal 300 ribu penderita Diabetes Mellitus. ${ }^{5}$ Meningkatnya penderita Diabetes Mellitus di Indonesia tidak lepas dari pola makan beresiko dan tidak adanya kesempatan atau kemauan untuk berolahraga.

Pengelolaan diabetes yang bertujuan untuk mempertahankan kadar glukosa darah dalam rentang normal dapat dilakukan secara nonfarmakologis dan farmakologis. Pengelolaan nonfarmakologis meliputi pengendalian berat 
badan, olah raga/latihan fisik/latihan jasmani dan diet. Terapi farmakologis meliputi pemberian insulin dan/atau obat hiperglikemia oral. ${ }^{10}$ Untuk mengurangi insiden Diabetes Mellitus yang semakin meningkat sebenarnya dalam penatalaksanaan terapi Diabetes Mellitus telah dikenal empat pilar utama dimana salah satunya adalah olah raga atau latihan fisik yang merupakan terapi guna mengurangi resiko terjadinya komplikasi seperti penyakit jantung dan pembuluh darah. ${ }^{6}$ Latihan fisik merupakan terapi yang sangat penting untuk mengontrol kadar gula darah serta menurunkan berat badan, namun perlu juga diwaspadai pada penderita dengan kadar glukosa yang sangat rendah, latihan fisik akan mengakibatkan kontrol gula darah makin rendah. ${ }^{5}$

Kunci sukses pengelolaan penyakit Diabetes Mellitus adalah kepatuhan dalam melaksanakan regimen terapi. Kepatuhan penderita Diabetes Mellitus dalam menjalankan terapi baik farmakologi maupun non farmakologi dapat mengurangi komplikasi. ${ }^{10}$ Penyuluhan kesehatan untuk penderita Diabetes Mellitus sangat berarti dalam membantu perawatan penderita untuk mencegah timbulnya komplikasi. Salah satunya adalah dengan cara memberikan informasi cara-cara melakukan latihan fisik guna menambah pengetahuan penderita Diabetes Mellitus tentang efek dan latihan fisik. Dalam hal ini keluarga dan perawat sangat penting, peran keluarga sebagai motivasi pendorong dukungan yang paling dekat dengan penderita, sedangkan peran perawat membantu penderita dan keluarga dalam menyampaikan informasi dan pandangan yang nyata terhadap penatalaksanaan Diabetes Mellitus. Berdasarkan latar belakang diatas tersebut peneliti ingin mengetahui hubungan pengetahuan dengan kepatuhan penderita DM dalam melakukan latihan fisik di Desa Tegal Wangi 4 Bantul Yogyakarta.

\section{METODE}

Penelitian ini menggunakan desain korelasi dengan pendekatan cross sectional artinya tiap subyek penelitian hanya diobservasi sekali saja dan pengukuran dilakukan terhadap status karakter atau variabel subyek pada saat pemeriksaan. Pada penelitian ini sampel penelitian adalah responden penderita diabetes mellitus di desa tegal wangi 4 Bantul Yogyakarta sebanyak 39 responden yang didapatkan sesuai dengan yang dikehendaki peneliti (purposive sampling). Pengukuran pengetahuan dan kepatuhan dengan menggunakan kuesioner yang sudah teruji validitas dan reliabilitasnya. Pengolahan data dengan menggunakan koding, skoring, tabulasi, dan menggunakan uji korelasi Spearman Rank Test dengan nilai signifikansi 0,05 .

Penelitian dilakukan di Desa Tegal Wangi 4 Bantul Yogyakarta, Bulan Januari 2015. Variabel bebas dalam penelitian ini adalah pengetahuan, sedangkan variabel terikat dalam penelitian ini adalah kepatuhan penderita diabetes mellitus dalam melakukan latihan fisik.

\section{HASIL}

Tabel 1 Karakteristik Responden Berdasarkan Umur

\begin{tabular}{cccc}
\hline No & $\begin{array}{c}\text { Umur } \\
\text { (thn) }\end{array}$ & f & \% \\
\hline 1 & $45-50$ & 11 & $28,2 \%$ \\
2 & $51-55$ & 16 & $41,0 \%$ \\
3 & $56-60$ & 8 & $20,5 \%$ \\
4 & $61-65$ & 4 & $10,3 \%$ \\
\hline & Jumlah & 39 & $100 \%$ \\
\hline
\end{tabular}

Berdasarkan Tabel 1 menunjukkan bahwa sebagian besar responden berada pada rentang umur 51-55 tahun yaitu sebanyak 16 responden (41\%). Dalam hal ini, umur tidak berpengaruh secara signifikan terhadap pengetahuan dan kepatuhan responden dalam melakukan latihan fisik.

Tabel 2 Karakteristik Responden Berdasarkan Jenis Kelamin

\begin{tabular}{llcc}
\hline No & $\begin{array}{l}\text { Jenis } \\
\text { Kelamin }\end{array}$ & Jumlah & Frekuensi \\
\hline 1 & Laki-laki & 19 & $48,7 \%$ \\
2 & Perempuan & 20 & $51,3 \%$ \\
\hline & Jumlah & 39 & $100 \%$ \\
\hline
\end{tabular}

Berdasarkan Tabel 2 menunjukkan bahwa sebagian besar responden berjenis kelamin perempuan yaitu sebesar 20 responden $(51,3 \%)$. Dalam hal ini, jenis kelamin tidak berpengaruh secara signifikan terhadap pengetahuan dan kepatuhan responden dalam melakukan latihan fisik. 
Tabel 3 Karakteristik Responden Berdasarkan Pendidikan

\begin{tabular}{llcc}
\hline No & Pendidikan & f & \% \\
\hline 1 & SD & 3 & $7,7 \%$ \\
2 & SMP & 7 & $17,9 \%$ \\
3 & SMA & 21 & $53,8 \%$ \\
4 & SARJANA & 8 & $20,5 \%$ \\
\hline & Jumlah & 39 & $100 \%$ \\
\hline
\end{tabular}

Berdasarkan Tabel 3 menunjukkan bahwa sebagian besar responden memiliki tingkat pendidikan SMA yaitu sebesar 21 responden $(53,8 \%)$. Dalam hal ini, pendidikan berpengaruh secara signifikan terhadap pengetahuan dan kepatuhan responden dalam melakukan latihan fisik.

Tabel 4 Karakteristik Responden Berdasarkan Status Kesehatan

\begin{tabular}{lllc}
\hline No & $\begin{array}{c}\text { Status } \\
\text { Kesehatan }\end{array}$ & f & \% \\
\hline 1 & Lama & 27 & $69,2 \%$ \\
2 & Baru & 12 & $30,8 \%$ \\
\hline & Jumlah & 39 & $100 \%$ \\
\hline
\end{tabular}

Berdasarkan Tabel 4 menunjukkan bahwa lebih dari sebagian besar responden memiliki status kesehatan lama sebagai penderita DM yaitu sebesar 27 responden $(69,2 \%)$. Dalam hal ini, status kesehatan berpengaruh secara signifikan terhadap pengetahuan dan kepatuhan responden dalam melakukan latihan fisik.

Tabel 5 Karakteristik Responden Berdasarkan Pekerjaan

\begin{tabular}{llcc}
\hline No & Pekerjaan & f & \% \\
\hline 1 & IRT & 12 & $30,8 \%$ \\
2 & Wiraswasta & 3 & $7,7 \%$ \\
3 & Pegawai & 8 & $20,5 \%$ \\
& Swasta & & \\
4 & PNS & 16 & $41,0 \%$ \\
\hline & Jumlah & 39 & $100 \%$ \\
\hline
\end{tabular}

Berdasarkan Tabel 5 menunjukkan bahwa hampir sebagian besar responden memiliki pekerjaan sebagai PNS yaitu sebesar 16 responden (41\%). Dalam hal ini, pekerjaan berpengaruh secara signifikan terhadap pengetahuan dan kepatuhan responden dalam melakukan latihan fisik.

Tabel 6 Pengetahuan penderita DM melakukan latihan fisik

\begin{tabular}{clcc}
\hline No & Pengetahuan & f & \% \\
\hline 1 & Kurang & 3 & $7,7 \%$
\end{tabular}

\begin{tabular}{lllc}
2 & Cukup & 20 & $51,3 \%$ \\
3 & Baik & 16 & $41,0 \%$ \\
\hline & Jumlah & 39 & $100 \%$ \\
\hline
\end{tabular}

Berdasarkan tabel 6 menunjukkan bahwa sebagian besar responden memiliki tingkat pengetahuan yang cukup mengenai latihan fisik pada penderita DM yaitu sebesar 20 responden (51,3\%). Responden yang memiliki pengetahuan baik sebanyak 16 responden (41\%). Dan sebagian kecil responden sebesar 3 responden (7,7\%) memiliki pengetahuan yang kurang tentang latihan fisik.

Tabel 7 Kepatuhan penderita DM dalam melakukan latihan fisik.

\begin{tabular}{clcl}
\hline No & Kepatuhan & f & \% \\
\hline 1 & Tidak Patuh & 12 & $30,8 \%$ \\
2 & Kurang Patuh & 19 & $48,7 \%$ \\
3 & Patuh & 8 & $20,5 \%$ \\
\hline & Jumlah & $\mathbf{3 9}$ & $\mathbf{1 0 0 \%}$ \\
\hline
\end{tabular}

Berdasarkan tabel 7 menunjukkan bahwa kepatuhan responden dalam melakukan latihan fisik diketahui hampir sebagian besar yaitu sebanyak 19 responden (48,7\%) kurang patuh dalam melakukan latihan fisik dan hanya sebagian kecil yaitu sebesar 8 responden $(20,5 \%)$ patuh dalam melakukan latihan fisik.

Hasil uji statistik dengan korelasi dari Spearman rank diperoleh nilai signifikansi $\mathrm{p}=0,000(\mathrm{p}<0,05)$, hal ini menunjukkan ada hubungan antara pengetahuan dengan kepatuhan penderita DM dalam melakukan latihan fisik.

Hasil uji statistik dengan cross tabulation antara pengetahuan dengan kepatuhan responden pada tabel 9 menunjukkan bahwa hampir sebagian besar responden kurang patuh dalam melakukan latihan fisik yaitu sebesar 19 responden (48,7\%). Dalam hal ini dari responden yang kurang patuh didukung juga dengan pengetahuan yang cukup baik sebesar 11 responden $(28,2 \%)$ dan memiliki pengetahuan yang baik sebesar 8 responden $(20,5 \%)$.

\section{PEMBAHASAN}

\section{Pengetahuan Responden mengenai Latihan Fisik.}

Berdasarkan tabel 6 menunjukkan bahwa sebagian besar responden memiliki tingkat pengetahuan yang cukup mengenai latihan fisik pada penderita DM yaitu sebesar 20 responden (51,3\%). Responden yang memiliki pengetahuan 
baik sebanyak 16 responden (41\%). Dan sebagian kecil responden sebesar 3 responden $(7,7 \%)$ memiliki pengetahuan yang kurang tentang latihan fisik.

Dalam hal ini pengetahuan responden dipengaruhi oleh pendidikan dan pekerjaan, serta status kesehatan. Pendidikan adalah sebagai proses perubahan sikap dan tata laku seseorang atau sekelompok orang dalam usaha mendewasakan manusia melalui upaya pengajaran dan latihan atau proses perubahan dan cara mendidik. ${ }^{10}$

Sosial ekonomi yang rendah akan mengurangi kemampuan keluarga untuk memenuhi kebutuhan-kebutuhan terhadap gizi, pendidikan dan kebutuhan-kebutuhan yang lain. ${ }^{6}$ Pengetahuan atau kognitif merupakan domain yang sangat penting untuk terbentuknya tindakan seseorang (over behavior). Penelitian Roger (1974) mengungkapkan bahwa sebelum seseorang mengadopsi perilaku baru dalam diri orang tersebut terjadi proses yang berurutan. ${ }^{2}$ Apabila penerimaan perilaku baru atau adaptasi perilaku melaui proses seperti didasari oleh pengetahuan, kesadaran dan sikap positif, maka perilaku tersebut akan bersifat langgeng (long lasting).

\section{Kepatuhan Responden dalam Melakukan Latihan Fisik.}

Berdasarkan tabel 7 menunjukkan bahwa kepatuhan responden dalam melakukan latihan fisik diketahui hampir sebagian besar yaitu sebanyak 19 responden $(48,7 \%)$ kurang patuh dalam melakukan latihan fisik dan hanya sebagian kecil yaitu sebesar 8 responden $(20,5 \%)$ patuh dalam melakukan latihan fisik.

Kepatuhan berasal dari kata dasar patuh, yang berarti disiplin dan taat. Menurut Sacket dalam Niven (2000) kepatuhan adalah sejauh mana perilaku pasien sesuai dengan ketentuan yang diberikan oleh professional kesehatan. ${ }^{5}$

Salah satu faktor yang menyebabkan ketidakpatuhan menurut Niven (2000) adalah pemahaman tentang instruksi, tak seorangpun dapat mematuhi instruksi jika dia salah paham tentang instruksi yang diberikan padanya. Selain itu, kualitas interaksi juga berpengaruh karena Kualitas interaksi antara professional kesehatan dan pasien merupakan bagian yang penting dalam menentukan derajat kepatuhan. Keluarga dapat menjadi factor yang sangat berpengaruh dalam menentukan keyakinan dan nilai keshatan individu serrta juga dapat menentukan program pengobatan yang dapat mereka terima. Becker et al (1979) dalam Niven (2000) telah membuat suatu usulan bahwa model keyakinan kesehatan berguna untuk memperkirakan adanya ketidakpatuhan. ${ }^{4}$

\section{Hubungan pengetahuan dengan kepatuhan penderita DM melakukan latihan fisik di Desa Tegal Wangi 4 Bantul Yogyakarta.}

Hasil uji statistik dengan korelasi dari Spearman rank diperoleh nilai signifikansi $(<$ $0,05)$, hal ini menunjukkan terdapat hubungan maka H1 diterima yang berarti ada hubungan antara pengetahuan dengan kepatuhan penderita DM dalam melakukan latihan fisik.

Hasil uji statistik dengan cross tabulation antara pengetahuan dengan kepatuhan responden pada tabel 9 menunjukkan bahwa hampir sebagian besar responden kurang patuh dalam melakukan latihan fisik yaitu sebesar 19 responden $(48,7 \%)$. Dalam hal ini dari responden yang kurang patuh didukung juga dengan pengetahuan yang cukup baik sebesar 11 responden $(28,2 \%)$ dan memiliki pengetahuan yang baik sebesar 8 responden (20,5\%).

Latihan fisik adalah suatu reaksi aksi energetik atau keadaan yang bergerak. ${ }^{9}$ Menurut Ahmad Husdin Asdie dikatakan bahwa jenisjenis latihan fisik atau olah raga yang memperbaiki kesegaran jasmani atau yang bertujuan untuk meningkatkan stamina yaitu memenuhi ketahanan, kekuatan, kelenturan, keseimbangan, ketangkasan, tenaga dan kecepatan. ${ }^{5}$

Menurut Brunner \& Suddarth (2002) Variabel psikososial mempengaruhi kepatuhan pasien dalam melakukan latihan fisik seperti intelegensia, sikap terhadap tenaga kesehatan, peneriamaan atau penyakalan terhadap penyakit, keyakinan agama atau budaya, dan biaya financial dan lainnya yang termasuk dalam mengikuti regimen hal tersebut diatas juga ditemukan leh Bart Smet dalam psikologi kesehatan.

Keluarga dapat menjadi factor yang sangat berpengaruh dalam menentukan keyakinan dan nilai keshatan individu serrta juga dapat menentukan program pengobatan yang dapat mereka terima. Derajat ketidakpatuhan itu ditentukan oleh beberapa faktor, yaitu: kompleksitas prosedur pengobatan, derajat perubahan gaya hidup yang dibutuhkan, lamanya waktu dimana pasien harus mematuhi program tersebut, apakah penyakit tersebut benar-benar menyakitkan, apakah pengobatan itu berpotensi menyelamatkan hidup, keparahan penyakit yang dipersepsikan sendiri oleh pasien bukan petugas kesehatan.

Salah satu strategi yang dapat digunakan untuk meningkatkan kepatuhan adalah dukungan 
profesional kesehatan. Dukungan professional kesehatan sangat diperlukan untuk meningkatkan kepatuhan, contoh yang paling sederhana dalam hal dukungan tersebut adalah dengan adanya teknik komunikasi. Komunikasi memegang perenan penting karena komunikasi yang baik diberikan oleh professional kesehatan baik dokter/perawat dapat menanamkan ketaatan bagi pasien, serta Pemberian informasi yang jelas pada pasien dan keluarga mengenai penyakit yang dideritanya serta cara pengobatannya.

\section{SIMPULAN}

Sebagian besar responden memiliki tingkat pengetahuan yang cukup mengenai latihan fisik pada penderita DM. Hampir sebagian besar yaitu sebanyak 19 responden $(48,7 \%)$ kurang patuh dalam melakukan latihan fisik dan hanya sebagian kecil yaitu sebesar 8 responden $(20,5 \%)$ patuh dalam melakukan latihan fisik. Terdapat hubungan maka H1 diterima yang berarti ada hubungan antara pengetahuan dengan kepatuhan penderita DM dalam melakukan latihan fisik.

\section{SARAN}

Penelitian ini diharapkan dapat memberikan manfaat bagi responden dalam program peningkatan kualitas hidup penderita DM melalui latihan fisik secara teratur. Hasil penelitian ini dapat dijadikan sebagai acuan untuk meningkatkan pelayanan pada pasien DM yang mengarah pada kebutuhan pasien dalam melakukan latihan fisik.

\section{DAFTAR PUSTAKA}

1. Mangoenprasodjo, Setiono. 2005. Hidup Sehat dan Normal Dengan Diabet. Thinkfresh. Yogyakarta.

2. Notoatmodjo, Soekidjo. 2003. Ilmu kesehatan Masyarakat. PT. Rineka Cipta. Jakarta.

3. Notoatmodjo, Soekidjo. 2003. Pendidikan dan Perilaku Kesehatan. PT. Rineka Cipta. Jakarta.

4. Tjokroprawiro, Askandar. 2002. Мепијu Hidup Sehat Bersama DM. Gramedia Pustaka. Jakarta.

5. Tjokroprawiro, Askandar. 2002. Hidup Sehat dan Bahagia Bersama DM. Gramedia Pustaka. Jakarta.

6. Devartz, 2010. Manfaat Jalan Kaki. Jurnal : http://id.shovoong.com (diakses tanggal 25 April 2014).

7. Fajar, I, dkk. Statistika untuk Pratiksi Kesehatan. Jogjakarta : Graha Ilmu.
8. Junaidi, S. 2011. Pembinaan Fisik Lansia melalui Aktivitas Olahraga Jalan Kaki. Jurnal. Semarang : UNES. http://journal.unnes.ac.id (diakses tanggal 26 Februari 2013 )

9. Potter, P. A.,dkk. 2006. Buku Ajar Fundamental Keperawatan. Jakarta: EGC

10. Setiaharjo, 2006. Penilaian Keseimbangan dengan Aktifitas sehari-hari Pada Lansia. Jurnal. Semarang: UNDIP (akses 28 April 2014). 